\begin{abstract}
Arnaldo Cantani*
Department of Pediatrics, Allergy and Clinical Immunology Division, University of Rome "La Sapienza", Rome, Italy

Dates: Received: 08 June, 2015; Accepted: 07 August, 2015; Published: 10 August, 2015

*Corresponding author: Arnaldo Cantani, Professor Allergy and Immunology Division, Department of Pediatrics, University of Rome "La Sapienza", Roma, Italy, E-mail: acantani13@gmail.com

www.peertechz.com
\end{abstract}

Keywords: Genetic disease; Atopic march; Early onset; Atopic dermatitis; Food allergy: Asthma; Allergic rhinitis; Infants, Children

\author{
Review Article
}

\section{A Great Discovery Allergy and Asthma are fully Genetic in Children}

\section{Introduction}

Few diseases like atopic dermatitis, although not being lethal, are causes of invaluable physical and emotional suffering either for children or their parents. Needless to say, there are also growing numbers of wheezing infants at an early age. There appears to be a belief that asthma in children is increasing. Given the fact that the morbidity of asthma has not decreased despite many advances in pharmacologic treatment, it is clear that attempting at reduce exposure should come at an early stage of life [1]. Actually, several data are explaining why atopic diseases are increasing in prevalence in Western countries: "Before birth" is the key, the suggestive site where the origin of atopy was recently unveiled [2-7]. Therefore allergic and immunologic disorders, before being diagnosed in adult patients, start in the fetus, in the neonate, in the infant, that are the youngest pediatric populations. So very soon severe atopic disorders confront doctors with one of the most demanding challenges.

Strongly associated is a positive family history [8], especially maternal in case of asthma [9], although several environmental determinants have been reported [10]. Several scientific advances have shed light in the past few years on the cell interactions that are pivotal in orchestrating the inflammation underlying atopy. In particular we can now understand how strictly are linked with atopy the genetic factors: several cytokine genes are associated in the gene cluster of chromosome 5q23-q31, such as IL-3, IL-4, IL-5, IL-9, IL-12b, IL-13, and GM-CSF, together with the genes for the 32 -adrenergic receptor
[11]. There is a significant linkage between total IgE levels and several of these markers, particularly IL-4R [12] and IL-9 [13]. A linkage of chromosome markers with bronchial hyperreactivity (BHR) and total IgE concentrations has been reported [14]. Two genes account for $78 \%$ of the genetic predisposition to high IgE levels [15]. However this linkage has not been confirmed by others, either for total serum IgE or for BHR $[16,17]$ The genes for the $§$ subunit of the high affinity immunoglobulin E receptor (FceRI-ß) are located on 11q13 [18], and are associated, but without a complete unanimity of researchers, with one or more genes coding for atopy [11]. The initial study showing a dominant gene on this chromosome [19] has been confirmed [20-24] or not [25-30], while an association between high serum IgE levels and D11S97 on chromosome 11q has been found in Japanese subjects [31]. There is no association of atopic dermatitis with chromosome 11q [32], but with the FceRI- $B$ [33]. Other genes located on 14q23, $14 \mathrm{q} 32$, and $14 \mathrm{q} 11.2$ may contain loci predisposing to high IgE levels, while those on 12q15 and 12q24 are associated with IFN-g concentrations [11] and show linkage with asthma and total serum $\operatorname{IgE}[34]$.

Overall, a more suggestive link is an early sensitization within the first-third years of life mediated by indoor allergen exposure $[35,36]$.

\section{Personal Studies}

In the following [37-58] we have meta-analyzed the results of several epidemiological studies, which enable me to present here a 
state-of-the-art report on the onset of the atopic march, focusing on the early and also very early onset in several cases.

When it is well known that atopic dermatitis [37-42] and food allergy [43-49] have their onset within the first year of life in $70-100 \%$ of infants [37-42], and in the second in $69-96 \%$ of cases [43,44], it may not be clear that allergy to a panel of foods begins before the first year of age in a wide proportion of babies [45-49]. For example allergy to cow milk evidently begins in at least $72 \%$, and to egg in $71 \%$ of infants [45-47]. However the percentages of 52,3\% for fish, and of $62 \%$ for cereals can be unexpected, and even more the rates of legumes, fruits, and nuts [45-47]. The case of peanuts depends on the country where the study was done $[48,49]$, whereas chocolate has been absolved [45].

The asthma affair is a little more intricate: the onset within the first year is certain in $34,5 \%[37,38,51,52]-56,2 \%$ [38,54] of babies, but a higher level $[82,4 \%]$ is evident between the 4 th and the 7 th year [38,54-56]. That within the 8th year the asthma onset is manifest in $90 \%$ of children [55] is confirmed by the $92 \%$ proportion reached in children less than 20 years of age [57]. The sex difference may be 1,65: 1 at $0-1$ years, but it is inversely or practically abrogated within the 8 th year [38].

As regards allergic rhinitis, the onset may be in the first year in $35 \%$ of children and in $59 \%$ of those aged $2-5$ years [38], who in other studies are affected in $13-19 \%$ of cases [28,37]. The sex difference is high between $4-10$ years for males $(2,3: 1)$, but in older children it seems to disappear [37].

\section{Discussion}

This meta-analysis was facilitated by the selection of only one factor, the age, though a cause of variability can be the wide range of disease definitions, especially for asthma. However only in preschool children a definite diagnosis of asthma may be difficult to establish since many wheezing infants lose their symptoms in the first years of life [59]. On the other side, lack of information on the development of the atopic march early in life may confound the interpretation of early changes. Therefore the role of pediatric allergists is also to be highlighted in view of the early onset of atopic disease, which stresses the pivotal and crucial place held by such specialists in the early diagnosis and treatment of young children.

The early onset of the atopic march is favored in the first place by cow milk allergy [45-47], a peculiar form of allergic disease in which IgE antibodies are directed to introduced daily proteins [4]. The reduction of specific CD8 response could play a crucial role in the dysregulation of IL4 production in at risk babies, and probably in the breakthrough of oral tolerance towards cow milk proteins [4]. Sensitization to foods occurs more commonly early in life, however occasionally it may even occur prenatally. Cow milk appears to be the most common offending food both in gastrointestinal (vomiting, diarrhea, etc.), and in cutaneous manifestations (urticaria and atopic dermatitis). Specific IgE to foods and positive challenge test to a number of food allergens are frequently present in children with such disorders. Food allergy and atopic dermatitis may negatively interfere with the child's life and his physical and physiological development. Prevention should be therefore the early mainstay of each intervention. According to previous and recent studies, prevention of atopic diseases in genetically predisposed newborn babies, is not only worthwhile [60] but also necessary. The family should have clear advice on the prevention of atopy [61]. We have stressed the negative effects of the maternity wards. To avoid the possible risks it should be clearly stated that giving any formula in the first few days of life is strictly forbidden unless prescribed by a pediatrician or demanded by a mother who is unwilling or incapable to breastfeed her baby [62]. It may also happen that $12 / 65$ (18.5\%) mothers included in a preventive program mistakenly eat cow milk and/or fish [63], or offspring's from bilateral atopic parents eat egg at the insistence of the grandmother [62].

A general improvement of the pediatric atopic population seems an unrealistic goal at the moment, however their management should be in the hands of well-trained pediatricians and pediatric allergists, and not in the hands of the various "alternative" practitioners using methods such as homeopathy, bioresonance, auriculo-acupressure, and the like [64], with serious and even dangerous results [65]. We know that postponing the atopy development leads to a lessening of the severity of the clinical manifestations, and even to atopy avoidance forever [66]. Once atopy develops, it is now possible to prevent the clinical manifestations in a great proportion of cases (secondary prevention) by the use of pharmacological agents such as cromons and ketotifen [66]. In addition as demonstrated by the ETAC study it is possible to prevent the onset of respiratory allergy in 50\% of babies with atopic dermatitis following an 18-month administration of cetirizine [67]. Since the commitment to the Th2 phenotype in atopics appears to occur at any time between the ages of 2 and 5 years [68], the net implication is that within the first years of life there is a window open for immunoprophylaxis [69]. Moreover, dietary prevention is not sufficient if it is not accompanied by strict environmental measures. Possible obstacles confront any allergy prevention program $[35,36,70]$, that should instead balance the contributing factors to the increase of indoor allergens [70]. In the environment we find aeroallergens to be prevented, among which the leaders, such as house dust mite, pets, pollens, molds, cigarette smoke, and the indoor and outdoor air pollution [71-73].

"An ounce of prevention is worth a pound of cure". If we cannot change the atopic inheritance after birth, we can start early and effective preventive measures also before birth. This issue appears to lay in a realm almost to be described as a "no-man's land". Mother Nature teaches that in the neonatal immature gut the first line of defense is formed by some specialized factors. It may be that this first line should be moved forward [74]. I would like to stress, according to the Latin wisdom that stands on the portal of our Clinic "in puero homo ", which means "In infant is the seed of the future man", that the goal is not only to reduce morbidity and mortality, but mainly to insure the best quality of life both to infants and adults.

\section{References}

1. Cantani A (1990) [Epidemiologia e prevenzione dell'allergia respiratoria nel bambino]. Eur Rev Med Pharmacol Sci 12: 147-157.

2. Jones AC, Miles EA, Warner JA, Warner JO (1995) IFNg production and proliferative responses from fetal leukocytes during 2 nd and 3rd trimester of pregnancy. J Allergy Clin Immunol 95: 380A. 
3. Jones AC, Miles EA, Warner JO, Colwell BM, Bryant TN, et al. (1996) Fetal peripheral blood mononuclear cell proliferative responses to mitogenic and allergenic stimuli during gestation. Pediatr Allergy Immunol 7: 109-116.

4. Parronchi $P$, Sampognaro S, Giannarini L, Ruffilli A, Chersi A, et al. (1996) T-cell response to milk proteins in atopic and nonatopic donors. Monogr Allergy 32: 121-129.

5. Piastra M, Stabile A, Fioravanti G, Castagnola M, Pani G, et al. (1994) Cord blood mononuclear cell responsiveness to ß-lactoglobulin: T-cell activity in "atopy-prone" and "non-atopy-prone" newborns. Int Arch Allergy Immunol 104: 358-365.

6. Szépfalusi Z, Nentwich I, Gerstmayr M, Jost E, Todoran L, et al. (1997) Prenatal allergen contact with milk proteins. Clin Exp Allergy 27: 28-35.

7. Piccinni M-P, Mecacci F, Sampognaro F, Manetti R, Parronchi $P$, et al. (1993) Aeroallergen sensitisation can occur during fetal life. Int Arch Allergy Immunol 102: 301-303.

8. Dold S, Wjst M, von Mutius E, Reitmer P, Stieper E (1992) Genetic risk for asthma, allergic rhinitis, and atopic dermatitis. Arch Dis Child 67: 1018-1022.

9. Moffatt MF, Cookson WOCM (1998) Maternal effects in atopic disease. Clin Exp Allergy 28: 56-61.

10. Sears MR, Holdaway MD, Flannery EM, Herbison GP, Silva PA (1996) Parental and neonatal risk factors for atopy, airway hyper-responsiveness, and asthma. Arch Dis Child 75: 392-398.

11. Anderson GG, Morrison JFJ (1998) Molecular biology and genetics of allergy and asthma. Arch Dis Child 78: 488-496.

12. Marsh DG, Neely JD, Breazeale DR, Ghosh B, Freidhoff LR, et al. (1994) Linkage analysis of IL-4 and other chromosome $5 q 31.1$ markers and total serum immunoglobulin E concentrations. Science 264: 1152-1156.

13. Meyers DA, Postma DS, Panhuysen CIM, Xu J, Amelung PJ, et al. (1994) Evidence for a locus regulating total serum IgE level mapping to chromosome 5. Genomics 23: 464-470.

14. Postma DS, Bleecker ER, Amelung PJ, Holroyd KJ, Xu J, et al. (1995) Genetic susceptibility to asthma - bronchial hyper responsiveness co inherited with a major gene for atopy. N Engl J Med 333: 894-900.

15. Xu J, Levitt RC, Panhuysen CMI, Postma DS, Taylor EW, et al. (1995 Evidence for two unlinked loci regulating total serum IgE levels. Am J Hum Genet 57: 425-430.

16. Sandford A, Daniels SE, James AL, LeSouëf PN, Musk AW, et al. (1995) Chromosome 5 markers, total $\mathrm{IgE}$ and bronchial responsiveness in a random population. Am J Respir Crit Care Med 151: 354A.

17. Walley AJ, Cookson WOCM (1997) Linkage and allelic association of chromosome 5 microsallite markers with atopic asthma phenotype in a general population sample. Am J Respir Crit Care Med 155: 257A.

18. Sandford A, Weir T, Paré P (1996) The genetics of asthma. Am J Respir Crit Care Med 153: 1749-1765.

19. Cookson WOCM, Hopkin JM (1988) Dominant inheritance of atopic immunoglobulin $\mathrm{E}$ responsiveness. Lancet 1: 86-88.

20. Cookson WOCM, Faux JA, Sharp PA, Hopkin JM (1989) Linkage between immunoglobulin $\mathrm{E}$ responses underlying asthma and rhinitis and chromosome 11q. Lancet 1: 1292-1295.

21. Amelung PJ, Panhuysen CIM, Postma DS, Levitt RC, Koeter GH, et al (1992) Atopy and bronchial hyper responsiveness: exclusion of linkage to markers on chromosome 11q and 6p. Clin Exp Allergy 22: 1077-1084.

22. Collée JM, ten Kate LP, de Vries HG, Kliphuis JW, Bouman K, et al. (1993) Allele sharing on chromosome $11 \mathrm{q} 13$ in sibs with asthma and atopy [ letter]. Lancet 342: 936.

23. Shirakawa T, Mao X-Q, Sasaki S, Enomoto T, Kawai M, et al. (1996) Association between atopic asthma and a coding variant of the FceRIß in a Japanese population. Hum Mol Genet 5: 1129-1130.
24. Young RP, Sharp PA, Lynch JR, Faux JA, Hopkin JM (1992) Confirmation of genetic linkage between atopic IgE response and chromosome 11q13. J Med Genet 29: 236-238.

25. Lympany P, Welsch K, McCockrane G, Kemeny DM, Lee TH (1992) Genetic analysis using DNA polymorphism of the linkage between chromosome $11 \mathrm{q} 13$ and atopy and bronchial responsiveness to metacholine. J Allergy Clin Immunol 89: 619-628.

26. Lympany P, Welsch K, McCockrane G, Kemeny DM, Lee TH (1992) Genetic analysis of the linkage between chromosome $11 q 13$ and atopy. Clin Exp Allergy 22: 1085-1092.

27. Hizawa N, Yamaguchi E, Ohe M, Itoh M, Furuya K, et al. (1992) Lack of linkage between atopy and locus 11q13. Clin Exp Allergy 22: 1065-1069.

28. Rich SS, Roitman-Johnson B, Greenberg B, Roberts S, Blumenthal MN (1992) Genetic analysis of atopy in three large kindreds: no evidence of linkage to D11S97. Clin Exp Allergy 22: 1070-1076.

29. Brereton HM, Ruffin RE, Thompson PJ, Turner DR (1994) Familial atopy in Australian pedigrees: adventitious linkage to chromosome 8 is not confirmed nor is there evidence of linkage to the high affinity IgE receptor. Clin Exp Allergy 24: 868-877.

30. Amelung PJ, Postma DS, Xu J, Meyers DA, Bleecker ER (1998) Exclusion of chromosome 11q and the FceRI- $\beta$ gene as etiological factors in allergy and asthma in a population of Dutch asthmatic families. Clin Exp Allergy 28: $397-$ 403.

31. Hizawa N, Yamaguchi E, Furuya K, Ohnuma N, Kodama N, et al. (1995) Association between high serum IgE levels and D11S97 on chromosome 11q in Japanese subjects. J Med Genet 32: 363-369.

32. Coleman R, Trembath R, Harper JI (1993) Chromosome 11q13 and atopy underlying atopic eczema. Lancet 341: 1121-1122.

33. Cox HE, Moffatt MF, Faux JA, Walley AJ, Coleman R, et al. (1998) Association of atopic dermatitis to the beta subunit of the high affinity immunoglobulin $E$ receptor. Br J Dermatol 138: 182-187.

34. Barnes KC, Neely JD, Duffy DL, Freidhoff LR, Breazeale DR, et al. (1996) Linkage of asthma and total serum IgE concentration to markers on chromosome 12q: evidence for Afro-Caribbean and Caucasian populations. Genomics 37: 41-50.

35. Björkstén F (1986) Early allergen contacts. J Allergy Clin Immunol 86: 1010 1012.

36. Wahn U, Kulig M, Lau S, Kulig M, Forster J, et al. (1997) Indoor allergen exposure is a risk factor for early sensitization during the first three years of life. J Allergy Clin Immunol 99: 763-769.

37. Blair H (1974) The incidence of asthma, hay fever and infantile eczema in an East London group practice of 9145 patients. Clin Allergy 4: 389-399.

38. Koivikko A (1974) Childhood asthma in Finland. Acta Allergol 29: 30-72.

39. Queille-Roussel C, Raynaud F, Saurat J-H (1985) A prospective computerized study of 500 cases of atopic dermatitis in childhood. Acta Derm Venereol 114: 87-92.

40. Kay J, Gawkrodger DJ, Mortimer MJ, Jaron AG (1994) The prevalence of childhood atopic eczema in a general population. J Am Acad Dermatol 30: 35-39.

41. Musgrove K, Morgan JK (1976) Infantile eczema. A long-term follow-up study. Br J Dermatol 95: 365-372.

42. Guillet G, Guillet M-H (1992) Natural history of sensitizations in atopic dermatitis. Arch Dermatol 128: 187-192.

43. Crespo JF, Pascual C, Burks AW, Helm RM, Esteban MM (1995) Frequency of food allergy in a pediatric population from Spain. Pediatr Allergy Immunol 6: 39-43.

44. Bock SA (1987) A prospective appraisal of complaints of adverse reactions to foods in children during the first 3 years of life. Pediatrics 79: 683-688. 
45. Quiros AB, Villares ES (1988) Pathogenic basis of food allergy treatment Nestlé Nutr Workshop Ser 17: 265-270.

46. Martin Esteban M, Pascual C, Diaz Pena JM, Ojeda JA (1992) Basi patogenetiche per la profilassi ed il trattamento dell'allergia alle proteine de latte di vacca. In: Allergie alimentari. Roma: Fisons Italchimici SpA 105-117.

47. Bardare M, Zani G, Magnolfi C (1992) Evoluzione della dermatite atopica ad insorgenza nei primi anni di vita. In: Allergie alimentari. Roma: Fisons Italchimici SpA 157-165.

48. Ewan PW (1996) Clinical study of peanut and nut allergy in 62 consecutive patients: new features and associations. BMJ 312: 1074-1078.

49. Zeiger RS, Heller S, Mellon M, Forsythe A, O'Connor R, et al. (1989) Effect of combined maternal and infant food-allergen avoidance on development of atopy in early infancy: a randomized study. J Allergy Clin Immunol 84: 72-89.

50. Croner S, Kjellman N-IM (1990) Development of atopic disease in relation to family history and cord blood IgE levels. Pediatr Allergy Immunol 1: 14-20.

51. Croner S, Kjellman N-IM (1992) Natural history of bronchial asthma in childhood. A prospective study from birth up to $12-14$ years of age. Allergy 47 : 150-157

52. Businco L, Falconieri P, Zannino L (1993) Presentazione dei risultati di uno studio policentrico epidemiologico delle malattie allergiche in età evolutiva in Italia. Notiz Allergol 12: 275-278.

53. Silverstein MD, Reed CE, O'Connell EJ, Melton LJ, O'Fallon WM, et al (1994) Long-term survival of a cohort of community residents with asthma. N Engl J Med 331: 1537-1541.

54. Gergen PJ, Turkeltaub PC, Kramer RA (1992) Age of onset in childhood asthma: data from a national cohort. Ann Allergy 68: 507-514.

55. Bergmann RL, Bergmann KE, Lau-Schadensdorf S, Luck W, Dannemann A et al. (1994) Atopic disease in infancy. The German multicenter atopy study (MAS-90). Pediatr Allergy Immunol 5: 19-25.

56. Linna O, Kokkonen J, Lahtela P, Tammela O (1992) A 10-year prognosis for generalized infantile eczema. Acta Pædiatr 81: 1013-1016.

57. Jenkins MA, Hopper JL, Bowes G, Carlin JB, Flander LB, et al. (1994) Factors in childhood as predictors of asthma in adult life. BMJ 309: 90-93.

58. Wüthrich B (1989) Epidemiology in the allergic diseases: are they really on the increase? Int Arch Allergy Appl Immunol 90: 3-10.

59. Martinez FD, Wright AL, Taussig LM, Holberg CJ, Halonen M, et al. (1995) Asthma and wheezing in the first six years of life. The Group Health Medical Associates. N Engl J Med 332: 133-138.
60. Kjellman M (1982) Prediction and prevention of atopic allergy. Allergy 37 463-473.

61. Kjellman N-IM (1992) Prevention of allergy - myth or reality? In Godard Ph, Bousquet J, Michel FB, eds. Advances in allergology and clinical immunology. Lancs: The Parthenon Publishing Group 401-414.

62. Hamburger RN, Hellers S, Mellon MH, O’Connor R, Zeiger RS (1983) Current status of the clinical and immunologic consequences of a prototype allergic disease prevention program. Ann Allergy 51: 281-290.

63. Hattevig G, Kjellman B, Sigurs N, Björkstén B, Kjellman N-IM (1989) The effect of maternal avoidance of eggs, cow's milk and fish during lactation upon allergic manifestations in infants. Clin Exp Allergy 19: 27-32.

64. Wüthrich B (1996) Epidemiology and natural history of atopic dermatitis. ACl Intern 8: 77-82.

65. Spigelblatt L, Laîné-Ammara G, Pless IB, Guyer A (1994) The use of alternative medicine by children. Pediatrics 94: 811-814.

66. Cantani A, Businco $L$ (1991) Prevention of atopic disease in at risk newborns. Allergie Immunol 23: 387-390.

67. ETAC Study Group. Allergic factors associated with the development of asthma and the influence of cetirizine in a double-blins, randomised, placebocontrolled trial: First results of ETAC. Pediatr Allergy Immunol [ in press]

68. Yabuhara A, Macaubas C, Prescott SL, Venaille TJ, Holt BJ, et al. (1997) Th2-polarized immunological memory to inhalant allergens in atopics is established during infancy and early childhood. Clin Exp Allergy 27: 12611269.

69. Holt PG (1994) A potential vaccine strategy for asthma and allied atopic diseases during early childhood. Lancet 344 : 456-458.

70. Björkstén B (1994) Risk factors in early childhood for the development of atopic diseases. Allergy 49: 400-407.

71. Chandra RK (1987) Environmental engineering in the prevention of atopic disease: how early is early enough? In Chandra RK, ed. Food Allergy. St John's: Nutrition Research Education Foundation 373-387.

72. Pauli G, Bessot JC, Dietemann A, de Blay F (1992) Prevention of mite asthma. In Godard Ph, Bousquet J, Michel FB, eds. Advances in allergology and clinical immunology. Lancs: The Parthenon Publishing Group 415-425.

73. Warner JO (1993) Environmental changes and asthma control in paediatrics. Paediatr Respir Med 1: 9-13.

74. Cantani A (1992) Phénomènes immunitaires locaux du tube digestif chez l'enfant et allergie alimentaire. Allergol Immunol 24: 199-205. 